\title{
Pemanfaatan Facebook sebagai media pembelajaran pendidikan agama islam pada masa pandemi Covid-19
}

\author{
Husna Nashihin a,1, ${ }^{*}$, Rani Efendi b,2, Suci Salmiyatun c,3 \\ a Universitas Wahid Hasyim Semarang, Jawa Tengah, Indonesia; \\ b Sekolah Tinggi Ilmu Tarbiyah Madani Yogyakarta, Yogyakarta, Indonesia; \\ c Sekolah Tingi Agama Islam NU Temanggung, Jawa Tengah, Indonesia; \\ *1 aufahusna.lecture2017@gmail.com; ${ }^{2}$ raniefendi123@gmail.com; ${ }^{3}$ sucisalmiya20@gmail.com \\ *Correspondent Author
}

Received:

Revised:

Accepted:

KAT AKUNCI

Facebook

Media Pembelajaran

Pandemi Covid-19.

\section{KEYWORDS}

Facebook

Learning Media

The Covid-19 pandemic
Latar belakang masalah dalam penelitian ini memasukkan teknologi pendidikan Facebook dalam dunia pendidikan agama Islam guna memudahkan proses kegiatan belajar mengajar. Facebook sebagai sebuah jejaring sosial pada dasarnya sangat efektif digunakan untuk media pebelajaran dan strategi pembelajaran PAI. Dari penerapan salah satu teknologi informasi khususnya facebook, maka seorang guru dapat dimudahkan dalam beberapa hal, yaitu; Para siswa cenderung antusias di dalam mengikuti pembelajaran, Seorang guru dapat lebih mudah mengakses dan memberikan penilaian secara online, Guru hanya memposisikan sebagai mentor dan para siswa dapat belajar secara mandiri sehingga mengalami secara langsung, Para siswa dengan mudah menemukan jawaban atas pertanyaan dan pernyataan yang disampaikan seorang guru, Pembelajaran tidak hanya dilakukan di kelas saja, tetapi dapat dilakukan dimanapun, tidak terikat jarak dan waktu, Penggunaan teknologi informasi yang tepat akan menciptakan pemanfaatan teknologi yang positif sehingga dapat fungsional. Dari beberapa kemudahan diatas, pembelajaran PAI yang digunakan di sekolah-sekolah pada umumnya akan lebih mudah dan mengikuti perkembangan zaman. informan yang tersedia tidak hanya satu, melainkan sangat banyak sumber yang memperkuat daya asah dan penasaran siswa untuk belajar lebih maju.

\section{The use of Facebook as a learning medium for Islamic religious education during the Covid-19 pandemic}

The background of the problem in this study includes Facebook's educational technology in the world of Islamic religious education in order to facilitate the process of teaching and learning activities. Facebook as a social network is basically very effective for learning media and PAI learning strategies. From the application of an information technology, especially Facebook, a teacher can be facilitated in several ways, namely; Students tend to be enthusiastic in participating in learning, a teacher can more easily access and provide online assessments, the teacher only positions as a mentor and students can learn independently so they experience firsthand, students easily find answers to questions and statements submitted a teacher, learning is not only done in the classroom, but can be done anywhere, not bound by distance and time. The use of appropriate information technology will create positive technology utilization so that it can be functional. From some of the facilities above, PAI 
learning used in schools will generally be easier and keep up with the times. There are not only one informant available, but very many sources that strengthen students' sharpening and curiosity to learn more advanced.

This is an open-access article under the CC-BY-SA license.

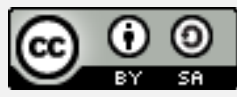

\section{Pendahuluan}

Sampai dua ratus tahun yang lalu ekonomi dunia bersifat agraris dimana salah satu ciri utamannya adalah tanah merupakan faktor produksi yang paling dominan. Sesudah terjadi revolusi industri, dengan ditemukannya mesin uap, ekonomi global berevolusi ke arah ekonomi industri dengan ciri utamanya adalah modal sebagai faktor produksi yang paling penting. Menjelang peralihan abad sekarang ini, cenderung manusia menduduki tempat sentral dala proses produksi, karena tahap ekonomi yang sedang kita masuki berdasar pada pengetahuan (knowledge based) berfokus pada informasi (information focused). Dalam hal ini telekomunikasi dan informatika memegang peranan sebagai teknologi kunci (enabler technology).

Perkembangan teknologi informasi sampai dengan saat ini berkembang dengan pesat seiring dengan penemuan dan pengembangan ilmu pengetahuan dalam bidang informasi dan komunikasi sehingga mampu menciptakan alat-alat yang mendukung perkembangan teknologi informasi, mulai dari sistem komunikasi sampai dengan alat komunikasi yang odal searah maupun dua arah (interaktif).

Teknologi informasi adalah suatu teknologi yang digunakan untuk mengolah data, termasuk memproses, mendapatkan, menyusun, menyimpan, memanipulasi, data dalam berbagai cara untuk menghasilkan informasi yang berkualitas, yaitu informasi yang yang relevan, akurat, dan tepat waktu, yang digunakan untuk keperluan pribadi, bisnis, dan pemerintahan dan merupakan informasi yang strategis untuk pengambilan keputusan. Teknologi ini menggunakan seperangkat komputer untuk mengolah data, sistem jaringan untuk menghubungkan satu komputer dengan komputer yang lainnya sesuai dengan kebutuhan, dan teknologi telekomunikasi digunakan agar data dapat disebardan diakses secara global.

Arus globalisasi pada masa sekarang ini tidak hanya masuk dalam dunia industri dan perekonomian saja, bergulirnya zaman, dunia pendidikan pun lambat laun terpengaruh dengan perkembangan arus ini. Teknologi sebagai alat utama sarana informasi dan telekomunikasi pada akhirnya juga akan mempengaruhi pendidikan pada umumnya. Pergeseran paradigma guru sebagai sumber pengetahuan agaknya mulai tergeser dengan informasi-informasi yang disediakan dalam teknologi. Seorang siswa tidak perlu bertanya banyak kepada guru, hanya cukup dengan mengakses internet saja mereka dapat mendapatkan informasi sebanyak-banyaknya tanpa perlu bertanya.

Teknologi informasi mempunyai dua wajah. Bisa berwajah positif apabila digunakan dan dimanfaatkan untuk hal posistif, berwajah negatif apabila digunakan untuk hal negatif pula. Dengan kata lain ditangan siapakah teknologi itu digunakan. Sebagai sebuah media memepermudah di dalam mengakses dan menyampaikan sesuatu, teknologi informasi menjadi hal yang urgent sehingga untuk memudahkan dalam semua bidang.

Dengan masuknya teknologi informasi dalam dunia pendidikan, hal tersebut tidak luput pula pada Pendidikan Agama Islam yang dimudahkan dengan fasilitas atau media ini. Dengan kata lain, seandainya guru PAI mampu memanfaatkan teknologi ini, maka secara bodon akan berimplikasi aktif terhadap pembelajaran. 
Facebook sebagai salah satu teknologi informasi dan jejaring sosial pada dasawarsa ini marak digunakan pada anak-anak usia remaja. Seorang anak cenderung menghabiskan waktunya untuk bercengkrama dengan dunia maya dibandingkan dengan dunia nyata. Dari faktor tersebut, penulis berusaha untuk menggali sejauhmanakah media facebook dapat diterapkan dalam pembelajaran.

Terdapat banyak pernyataan al-Qur'an dan Hadits mengenai kewajiban umat Islam untuk menyelidiki dan mempelajari alam semesta. Penyelidikan merupakan awal mula munculnya sains dan teknologi sebagai sebuah penemuan baru. Objektif pemerhatian penyelidikan mengenai alam semesta harus memenuhi dua objektif, yaitu mengenal secara terperinci hukum alam dan mengambil faedah darinya dari sudut gunaan atas sifat manusia adalah khalifah Allah. Dua hal ini harus diperhatikan secara seimbang dalam mengembangkan sains dan teknologi Islam.

Pada dasarnya ada dua pondasi utama atau substansial yang dirumuskan oleh sains Islam pada masa itu, yaitu tauhid dan hukum kausalitas yang bersumber pada alam semesta dan seisinya. Barat yang saat ini mengklaim sains dan teknologi yang maju saat ini sebagai kontribusi dari filsafat yunani, mengubur dalam-dalam ilmu tauhid yang telah dikembangkan dalam Islam. Mereka hanya mengembangkan hukum kausalitas untuk meneliti tentang alama semesta dan seisinya. Stagnansi agama dan semakin pesatnya sains dan teknologi yang berdasar pada hukum kausalitas menghasilkan sifat matrealistis, hedonis, dan sekuleristis, yang pada ahirnya memunculkan atheis di Barat. Hal ini menyebabkan perkembangan sains dan teknologi Barat saat ini jauh dari agama. Untuk itu, sebenarnya Barat saat ini sedang mengalami krisis kepercayaan terhadap Tuhan, sehingga terbukti dengan semakin bertambah pesatnya para saintist Barat yang memeluk agama Islam. Sebagai manusia yang sudah memilih Islam sebagai agama yang didyakini, seyogyanya juga harus mengimbangi kemampuan diri dengan penguasaan dan bahkan pengembangan sains dan teknologi.

Untuk itu, penting kiranya melakukan dekonstruksi dan redeskripsi lagi terhadap sains dan teknologi dalam Islam guna mengungkap kontribusi Islam dalam perkembangan sains dan teknologi. Hal ini penting dilakukan guna mengungkap kembali konsepsi sains yang sudah ada pada masa itu. Menurut Ziauddin Sardar, kelangsungan sains dan teknologi Islam selalu didasarkan atas asas nilai, konsep, dan nilai-nilai yang ada dalam Islam. Tauhid, khilafah, ibadah, halal, haram, adil dan zalim, istislah dan dhiya adalah asas penting yang ada dalam sains dan teknologi. Perpaduan antara konsepsi sains dan teknologi dalam Islam dengan asas Islam tersebut, akan melahirkan sains dan teknologi yang tidak hanya aplikatif tetapi juga normatif.

Guna mengungkap kontribusi nyata Islam dalam perkembangan sains dan teknologi, secara historis perlu diketahui mengenai konsepsi Islam tentang sains dan teknologi, kondisi sains dan teknologi pada masa kejayaan Islam, Perkembangan sains dan teknologi Islam, serta faktor penghambat kemajuan sains dan teknologi Islam.

Ahirnya, mudah-mudahan karya tulis ini dapat memberi manfaat bagi semua pembaca. Meskipun demikian penulis mengharap saran dan kritik demi kesempurnaan kaarya tulis ini.

\section{Metode}

Penelitian ini termasuk jenis penelitian literer yang menggunakan pendekatan teknologi pendidikan dalam mengkaji sumber-sumber implementasi teknologi pembelajaran yang digunakan di masyarakat. Penelitian kualitatif ini menggunakan metode pengumpulan data literer dengan sumber data berupa buku dan publikasi ilmiah lain yang relevan. Penelusuran sumber data dimulai dari pemetaan fokus penelitian. 


\section{Hasil dan Pembahasan}

\section{Globalisasi dan Teknologi}

Hasil dan Pembahasan dapat disajikan dalam subbab. Membahas secara jelas pokok bahasan sesuai dengan masalah, tujuan penelitian, dan teori yang digunakan.

Globalisasi telah memicu kecendrungan pergeseran dalam dunia pendidikan dar pendidikan tatap muka yang konvensional ke arah pendidikan yang lebih terbuka (Adipura, 2018) Sebagai awal tahun 70-an tentang "Pendidikan Tanpa Sekolah (Deschooling Society)" yang secara ekstrimnya guru tidak lagi diperlukan.

Bishop G. (1989) meramalkan bahwa pendidikan masa mendatang akan bersifat luwes (flexible) (Anshori, 2019), terbuka dan dapat diakses oleh siapa pun juga yang memerlukan tanpa pandang faktor jenis, usia, maupun pengalaman pendidikan sebelumnya. (Hariyanto, 2019) Mason R. (1994) berpendapat bahwa pendidikan mendatang akan lebih ditentungan oleh jaringan in formasi yang memungkinkan berinteraksi dan kolaborasi, bukannya gedung sekolah.

Namun teknologi akan memperlebar jurang antara si kaya dan si miskin.

Tony bates (1995) menyatakan bahwa teknologi dapat meningkatkan kualitas dan jangkauan bila digunakan secara bijak untuk pendidikan dan latihan, dan mempunyai arti yang sangat penting bagi kesejahteraan ekonomi Alisjahbana I. (1966) menegmukakan bahwa pendekatan pendidikan dan pelatihan nantinya akan bersifat "Saat itu juga (just on time)". Teknik pengajaran baru akan bersifat dua arah kolaboratif dan inter-disipliner. Romiszowski dan Mason memprediksi penggunaan "Computerbased Multimedia Communication (CMC)” yang bersifat singkron dan asinkron.

Dari ramalan dan pandangan dari para cendikiawan di atas dapat disimpulkan bahwa dengan masuknya pengaruh globalisasi, pendidikan masa mendatang akan lebih bersifat terbuka dan dua arah, beragam, multidisipliner, serta terkait dengan produktifitas kerja "saat itu juga" dan kompetitif. Kecenderungan dunia pendidikan di Indonesia di masa mendatang sebagai berikut; berkembangnya pendidikan terbuka dengan modus belajar jarak jauh (Distance Learning) kemudahan untuk menyelenggarakan pendidikan terbuka dan jarak jauh perlu dimasukkan sebagai strategi utama, sharing resourse bersama antar lembaga pendidikan/latihan dalam sebuah jaringan, perpustakaan dan instrument pendidikan lainnya (guru, laboratorium) berubah fungsi menjadi sumber informasi daripada sekedar rak buku, penggunaan perangkat teknologi teknologi informasi interaktif, seperti CD-ROM Multimedia, dalam pendidikan secara bertahap menggantikan TV dan Video.

\section{Teknologi dan Cybereducation}

Pengertian Teknologi sebenarnya berasal dari kata Bahasa Perancis yaitu "La Teknique" (Sudiksa, 2016) yang dapat diartikan dengan "Semua proses yang dilaksanakan dalam upaya untuk mewujudkan sesuatu secara rasional". Dalam hal ini yang dimaksudkan dengan sesuatu tersebut dapat saja berupa benda atau konsep, pembatasan cara yaitu secara rasional adalah penting sekali dipahami disini sedemikian pembuatan atau pewujudan sesuatu tersebut dapat dilaksanakan secara berulang (repetisi).

Teknologi dalam arti ini dapat diketahui melalui barang-barang, benda-benda, atau alatalat yang berhasil dibuat oleh manusia untuk memudahkan dan menggampangkan realisasi hidupnya di dalam dunia. Hal mana juga memperlihatkan tentang wujud dari karya cipta dan karya seni (Yunani techne) manusia selaku homo technicus. Dari sini muncullah istilah "teknologi", yang berarti ilmu yang mempelajari tentang "techne" manusia. Tetapi pemahaman seperti itu baru memperlihatkan satu segi saja dari kandungan kata "teknologi". Teknologi sebenarnya lebih dari sekedar penciptaan barang, benda atau alat dari manusia selaku homo technicus atau homo faber. Teknologi bahkan telah menjadi suatu sistem atau struktur dalam eksistensi manusia di dalam dunia. Teknologi bukan lagi sekedar sebagai 
suatu hasil dari daya cipta yang ada dalam kemampuan dan keunggulan manusia, tetapi ia bahkan telah menjadi suatu "daya pencipta" yang berdiri di luar kemampuan manusia, yang pada gilirannya kemudian membentuk dan menciptakan suatu komunitas manusia yang lain.

Dalam dunia pendidikan teknologi pendidikan lebih banyak dikenal dengan cybereducation.Cyber berasal dari bahasa Yunani, kubernan yang berarti memandu, mengarahkan, menguasai. Norbert Wiener, pada tahun 1948 menemukan istilah cybernetics untuk menggambarkan sistem pengontrolan yang menggunakan komputer. Sejak itu penggunaan awal cyber pun banyak bermunculan seperti cyberspace(1984) (Ramirez \& Garcia-Segura, 2017) cyberia, cybersex, cyberotics, dan cyberpunk. Dalam perkembangannya cyber lebih akrab dalam dunia teknologi sehingga berbagai bidang lain yang berkait dengan teknologi seringkali disandingkan dengan istilah cyber.

Seiring perkembangan berbagai bidang yang ada dalam kehidupan, pembelajaran juga ikut mengalami perkembangan yang cukup signifikan, yang disebut sebagai revolusi pembelajaran. Berbagai terobosan dalam pembelajaran telah ditemukan. Sebagian berasal dari guru-guru yang kompeten, sebagian dari dunia bisnis, sebagian dari psikologi, olah raga dan teknik-teknik kepelatihan. Istilah cybereducation pun muncul, sebagai salah satu bentuk pendidikan yang memanfaatkan peran teknologi. "ini hal yang baru yang menyenangkan dalam lahan pendidikan, terutama bagi pengajar, administrator, web designer, pengembang sistem dan semua pihak yang antusias pada pengembangan internet untuk pegajaran.

Gordon Dryden dan Jeannette Vos dalam bukunya The Learning Revolution menyatakan bahwa kita hidup di era pertama sepanjang sejarah manusia ketika setiap orang dapat berkomunikasi dengan siapa saja dan merupakan era pertama ketika anakanak lebih menguasai teknologi dominan dibandingkan para guru dan orang tua. Menurutnya pula, revolusi gabungan internet-komputer-Word Wide Web ini membentuk generasi baru yang lebih dahsyat dibandingkan revolusi yang dipicu oleh temuan percetakan, radio, mobil dan televisi.

Hal yang penting, revolusi digital memicu munculnya pemikiran ulang tentang metode belajar dan mengajar. Di bidang sains saja, sekitar 10.000 artikel baru dipublikasikan setiap hari. Tidak ada guru sains yang mampu membaca sebagian kecil saja apalagi semua materi tersebut.

\section{Teknologi sebagai Media dalam Pendidikan Agama Islam}

Secara umum 'media' (bentuk jamak dari 'medium') adalah "segala sesuatu yang membantu sampainya pesan dari pengirim kepada penerima" segala sesuatu fisik atau nonfisik, sudah ada (existing) atau buatan (artifak) membantu. Media bukan tujuan, hanya alat, salah memilih media dapat menyimpangkan pesan (distorsi / bias); terpaku pada media dapat mengaburkan pesan. Pesan segala sesuatu (pengetahuan, sikap, keterampilan) yang harus diterima / dimiliki oleh audiens (penerima pesan). Pengirim Seseorang / sekelompok orang yang menerima amanah/ mandat/perintah untuk menyampaikan pesan. Penerima Seseorang / sekelompok orang yang harus mengetahui/ melakukan sesuatu sesuai dengan isi pesan.

Secara harfiah kata media memiliki arti "Perantara" atau "pengantar". Associaton for Education and Comunication Technology (AECT) mendifinisikan media yaitu segala bentuk yang dipergunakan untuk suatu proses penyaluran informasi (Hokanson et al., 2020). Sedangkan Education Association (NEA) mendefinisikan sebagai benda yang dapat dimanipulasi, dilihat, didengar, dibaca atau dibicarakan beserta instrumen yang dipergunakan dengan baik dalam kegiatan belajar mengajar, dapat mempengaruhi efektifitas program instruktional.

Dari definisi-definisi tersebut dapat ditarik kesimpulan bahwa pengertian media merupakan sesuatu yang bersifatmenyalurkan pesan dan dapat merangsang pikiran, perasaan dan kemauan audiens sehingga dapat mendorong terjadinya proses belajar pada 
dirinya. Penggunaan media secara kreatif akan memungkinkan audien untuk belajar lebih baik dan dapat meningkatkan performan mereka sesuai dengan tujuan yang ingin dicapai.

Adapun Pendidikan agama Islam dapat diartikan sebagai usaha sadar, sistematis, berkelanjutan untuk mengembangkan potensi rasa agama, menanamkan sifat, dan membebaskan kecakapan sesuai dengan tujuan pendidikan islam.8 Pendidikan agama islam juga berarti upaya sadar dan terencana dalam menyiapkan peserta didik untuk mengenal, memahami, menghayati, mengimani, bertaqwa, dan berakhlak mulia mengamalkan ajaran islam dari sumber utama kitab suci Al-Qur'an dan hadist melalui bimbingan, pengajaran, latihan, serta pengalaman.9

Teknologi informasi sejatinya merupakan sebuah media untuk menggali dan menemukan informasi (Setiadi, 2016) lebih banyak terkait dengan pembelajaran yang disampaikan terutama pendidikan agama Islam. Adapun secara teoritik, media mempunyai beberapa fungsi, diantarannya:

\begin{tabular}{|c|c|}
\hline Alat & $\begin{array}{l}\text { Sesuatu (hardware/perangkat keras) nyang digunakan untuk } \\
\text { menyampaikan pesan yang tersimpan dalam bahan }\end{array}$ \\
\hline Sumber & $\begin{array}{l}\text { Contoh: Proyektor, slide, filmstrip, film, OHP, Video, Tape, Cassette } \\
\text { recorder, Pesawat radio, Pesawat TV dll }\end{array}$ \\
\hline Sumber & $\begin{array}{l}\text { Sesuatu (media atau software) yang mengandung pesan untuk } \\
\text { disajikan melalui penggunaan alat atau pun oleh dirinya sendiri }\end{array}$ \\
\hline Sumber & $\begin{array}{l}\text { Contoh : Transparansi, Slide, Film, Filmstrip, Audio tape, Video tape, } \\
\text { Buku, Modul, Majalah, Bahan } \\
\text { Pengajaran Terprogram dll }\end{array}$ \\
\hline \multicolumn{2}{|c|}{ Hubungan Belajar dan Media } \\
\hline Belajar & Perubahan tingkah laku disebabkan adanya suatu pengalaman \\
\hline Pengalaman & $\begin{array}{l}\text { Dibagi menjadi dua } \\
\text { Pengalaman langsung } \\
\text { Pengalaman tidak langsung }\end{array}$ \\
\hline Pengalaman Langsung & Peserta didik mengalami dan berbuat sendiri secara langsung \\
\hline $\begin{array}{l}\text { Pengalaman tidak } \\
\text { langsung }\end{array}$ & $\begin{array}{l}\text { Mengamati gejala atau situasi dengan menggunakan alat } \\
\text { Melalui gambar, grafik, bentuk verbal, lambang }\end{array}$ \\
\hline
\end{tabular}

\section{Pemanfaatan Teknologi Informasi Dalam Pendidikan}

Pengembangan Teknologi Pendidikan Teknologi pendidikan merupakan suatu disiplin ilmu terapan (Susanti, 2013), artinya ia berkembang karena adanya kebutuhan di lapangan, yaitu kebutuhan untuk belajar. Belajar lebih efektif, lebih efisien, lebih banyak, lebih luas, lebih cepat dan sebagainya. Untuk itu ada usaha dan produk yang sengaja dibuat dan ada yang ditemukan dan dimanfaatkan. Namun perkembangan teknologi pendidikan sangat pesat akhir-akhir ini dan menawarkan sejumlah kemungkinan yang semula tidak terbayangkan, telah membalik cara berpikir kita dengan Bagaimana mengambil manfaat teknologi tersebut 
untuk mengatasi masalah belajar?

Teknologi pendidikan adalah suatu cara yang sistematis dalam mendesain, melaksanakan dan mengevaluasi seluruh kegiatan proses belajar mengajar dalam mencapai tujuan pendidikan yang lebih baik (Imro'Atus et al., 2017). Dan Hamalik mengemukakan dalam bukunya bahwa pemakaian teknologi dalam proses belajar mengajar dapat membangkitkan keinginan dan minat yang baru, membangkitkan motivasi dan rangsangan kegiatan belajar, dan bahkan membawa pengaruh-pengaruh psikologis terhadap siswa. Kemajuan atau perkembangan teknologi pendidikan sekarang ini tidak terjadi begitu saja, tetapi Teknologi pendidikan mewadahi semua disiplin ilmu yang akan diselenggarakan dalam rangka pendidikan dan pembelajaran. Dalam kata lain, semua kegiatan pendidikan dan pembelajaran dapat mengintegrasikan teknologi pendidikan didalam proses penyampaiannya. Karena itu teknologi pendidikan memiliki fleksibilitas yang tinggi dalam pengembangan keilmuannya.

Oleh karena itu penggunaan teknologi pada tahap orentasi pendidikan akan sangat membantu keefektifan proses pembelajaran dan penyampaian pesan dan isi pelajaran pada proeses tersebut. Selain membangkitkan motivasi dan minat siswa, teknologi pendidikan juga dapat membatu siswa meningkatkan pemahaman, menyajikan data dengan menarik dan terpercaya, dan memudahkan dalam proses pembelajaran (Pangalo, 2020). Bersamaan dengan perubahan konsep teknologi pendidikan berdasarkan AECT bahwa Teknologi pendidikan adalah satu bidang atau disiplin ilmu dalam memfasilitasi belajar manusia melalui identifikasi, pengembangan, pengeorgnasiasian dan pemanfaatan secara sistematis seluruh sumber belajar. Rumusan teknologi pendidikan membentuk sebuah teori karena telah memenuhi kriteria adanya fenomina, penguraian dan penjelasan, pengikhtisaran, oreintasi, sistematiisasi, identifikasi keputusan, menciptakan strategi untuk penelitian, peramahan, dan adanya asas-asas atau prinsip- prinsip. Disamping itu teknologi pendidikan mengandung teknik intelektual yang unik, yaitu suatu cara pendekatan terhadap masalah. Setiap fungsi pengembangan dan pengelolaan mempunyai metode tersendiri, namun metode berpikir dalam teknologi pendidikan bukan hasil dari penjumlahan tiap-tiap metode tersebut, melainkan lebih luas.

Metode berpikir menurut teknologi (Maha, 2019) pendidikan mencakup pengintegrasian yang sistematis dan tiap metode yang dipakai bagi setiap fungsi berikut kesaling bergantugannya, diintegrasikan dalam satu susunan yang dipergunakan untuk menganalisis keseluruhan masalah guna menemukan masalah-masalah baru. Dengan demikian, metodologi itu menghasilkan pengaruh sinergistik, menolak hasil-hasil yang didasarkan atas unsure-unsur yang bekerja secara terpisah yang tak dapat diramalkan sepenunya. Teknologi pendidkian mempunyai aplikasi praktis, dengan adanya sumber-sumber belajar, berperannya tugas-tugas pengembanagan dan pengelolaan.

Lebih lanjut teknologi pendidikan mempengaruhi struktur organisatoris pendidikan (Habibah, 2017) sebab; Mempengaruhi secara langsung pengembangan kurikulum, Ia memberi alternatif bentuk pengajaran, yaitu mempergunakan sumber manusia, mempergunakan sumber-sumber lain kecuali manusia, menggunakan manusia dan sumbersumber lain yang dikombinasikan dalam sistem pengajaran dengan media pembelajaran, Memberi kemungkinan terbentuknya kelembagaan alternatif yang dapat menyediakan fasilitas belajar dan dapat melayani semua bentuk kelembagaan pendidikan. Aplikasi tersebut membawa inplikasi yang menguntungkan bagi proses pendidikan, misalnya mengubaha cara-cara pelaksanaan pendidikan, mengubah sikap Guru, menentukan isi termasuk setandarisasi, bahan desain, produksi, dan evaluasi pangajaran sistem panilaian, Teknologi pendidikan juga bermakna suatu yang integrasi, yang melibatkan manusia, prosedur, gagasan, peralatan dan organisasi untuk mengenalisis masalah-masalah pendidikan dan cara-cara pemecahannya, mencoba moel-model pemecahan, mengadakan penilaian dan mengelolanya. Dalam pemecahan masalah-masalah kependidikan, semua sumber belajar yang dirancang, dipilih dan digunakan untuk menciptakan kegiatan belajar. 
Sumber-sumber tersebut dinyatakan sebagai pesan, orang, materian, peralatan, metode, lingkungan atau situas. Proses dalam mengenalisis masalah-masalah kependidikan, menyusun cara-cara pemecahan masalah, pelaksanaan dan penilaian dinyatakan dengan fungsi pengembangan pendidikan yang menyangkut penelitian teori, dan utilasi diseminasi.

Proses pengarahan dan kordinasi pada satu atau lebih fungsi tersebut dinyatakan sebagai fungsi pengelolaan pendidikan diantara unsur-unsur tersebut yang tanpak jelas pada model berikut. Pengembangan keterampilan yang diperlukan dalam era informasi Peran penting integrasi Teknologi dalam proses pembelajaran adalah untuk membangun keterampilan peserta didik, keterampilan melek Teknologi dan media (media literacy skills), keterampilan berpikir kritis (critical thinking skills), keterampilan memecahkan masalah (problem-solving skills), keterampilan berkomunikasi efektif (effective communication skills), keterampilan bekerjasama secara kolaboratif (collaborative skills) Pengintegrasian Teknologi dalam proses pembelajaran harus memungkinkan siswa menjadi partisipan aktif, menghasilkan dan berbagi (sharing) pengetahuan /keterampilan serta berpartisipasi sebanyak mungkin serta belajar secara individu sebagai mana halnya juga kolaboratif dengan siswa lain.

\section{Facebook Sebagai Media Pembelajaran}

Sekilas Pandang Facebook; Facebook adalah sebuah layanan jejaring sosial yang diluncurkan pada bulan Februari 2004 (Retno, 2019), dimiliki dan dioperasikan oleh Facebook, Inc. Pada September 2012, Facebook memiliki lebih dari satu miliar pengguna aktif lebih dari separuhnya menggunakan telepon genggam.] Pengguna harus mendaftar sebelum dapat menggunakan situs ini. Setelah itu, pengguna dapat membuat profil pribadi, menambahkan pengguna lain sebagai teman, dan bertukar pesan, termasuk pemberitahuan otomatis ketika mereka memperbarui profilnya. Selain itu, pengguna dapat bergabung dengan grup pengguna dengan ketertarikan yang sama, diurutkan berdasarkan tempat kerja, sekolah atau perguruan tinggi, atau ciri khas lainnya, dan mengelompokkan teman-teman mereka ke dalam daftar seperti "Rekan Kerja" atau "Teman Dekat".

Facebook didirikan oleh Mark Zuckerberg bersama teman sekamarnya dan sesama mahasiswa Universitas Harvard, Eduardo Saverin, Andrew McCollum, Dustin Moskovitz dan Chris Hughes Keanggotaan situs web ini awalnya terbatas untuk mahasiswa Harvard saja, kemudian diperluas ke perguruan lain di Boston, Ivy League, dan Universitas Stanford. Situs ini secara perlahan membuka diri kepada mahasiswa di universitas lain sebelum dibuka untuk siswa sekolah menengah atas, dan akhirnya untuk setiap orang yang berusia minimal 13 tahun. Meski begitu, menurut survei Consumer Reports bulan Mei 2011, ada 7,5 juta anak di bawah usia 13 tahun yang memiliki akun Facebook dan 5 juta lainnya di bawah 10 tahun, sehingga melanggar persyaratan layanan situs ini.

Studi Compete.com bulan Januari 2009 menempatkan Facebook sebagai layanan jejaring sosial yang paling banyak digunakan menurut jumlah pengguna aktif bulanan di seluruh dunia Entertainment Weekly menempatkannya di daftar "terbaik" akhir dasawarsa dengan komentar, "Bagaimana caranya kita menguntit mantan kekasih kita, mengingat ulang tahun rekan kerja kita, mengganggu teman kita, dan bermain Scrabulous sebelum Facebook diciptakan? Quantcast memperkirakan Facebook memiliki 138,9 juta pengunjung bulanan di AS pada Mei 2011.] Menurut Social Media Today pada April 2010, sekitar 41,6\% penduduk Amerika Serikat memiliki akun Facebook.Meski begitu, pertumbuhan pasar Facebook mulai turun di sejumlah wilayah dengan hilangnya 7 juta pengguna aktif di Amerika Serikat dan Kanada pada Mei 2011.

Nama layanan ini berasal dari nama buku yang diberikan kepada mahasiswa pada tahun akademik pertama oleh beberapa pihak administrasi universitas di Amerika Serikat dengan tujuan membantu mahasiswa mengenal satu sama lain. Facebook memungkinkan setiap orang berusia minimal 13 tahun menjadi pengguna terdaftar di situs ini.

Pemanfaatan Facebook dalam Pembelajaran PAI; Seperti kita ketahui, banyak dari kalangan anak muda, khususnya anak sekolah pada saat ini lebih banyak berkutik pada 
jejaring sosial melalui alat-alat elektronik seperti HP, Laptop maupun alat-alat lainnya. Bahkan seorang anak cenderung lebih mudah dalam mendapatkan informasi dibandingkan oleh guru, sehingga seorang anak lebih banyak belajar pada teknologi informasi.

Facebook sebagai salah satu teknologi informasi dan salah satu jejaring sosial pada masa saat ini kurang dimanfaatkan oleh para pendidik, khususnya para guru agama Islam. Dengan melihat kenyataan yang ada, anak-anak pada masa sekarang lebih perhatian terhadap facebook dibandingkan dengan penjelasan guru yang cendrung monoton dan membosankan. Seorang anak lebih suka belajar dari media dibandingkan dengan informasi guru yang usang ditelan zaman. Peluang yang harusnya dimanfaatkan guru ternyata masih menjadi barang yang haram dan dianggap tidak berguna bagi guru. Paradigma ini merurut penulis sudah menjadi perhatian yang kronis bagi para pendidik.

Dengan keterbatasan pembelajaran yang mengalami pergeseran menuju pada student center, dan seorang guru bergeser dari seorang informan utama (primer) menjadi sekunder, maka pemanfaatan facebook sebagai idola siswa menjadi aspek urgent dan mendesak. Sebagai contoh : guru dapat menjadikan facebook sebagai sebuah media pembelajaran sehingga setiap anak yang membuka facebook tidak hanya bergelut pada komunikasi yang sia-sia dan juga lebih cenderung negatif. Sisi positif lainnya adalah guru dapat secara tidak langsung mengawasi tindak-tanduk keseharian siswa di luar sekolah sehingga dapat melakukan pengawasan secara proposional dan komprehensif. Dalam penerapan pembelajaran guru dengan sangat mudah melakukannya dengan langkah-langkah sebagai berikut :

Guru membuat aku Facebook terlebih dahulu, Guru mengadd atau siswa yang diminta guru untuk mengadd facebook guru, Di dalam akun facebook terdapat aplikasi group, maka disana guru dapat mengklasifikasikan siswa sesuai dengan kelasnya, Setelah siswa dan guru berteman, maka proses pembelajaran dapat dilakukan dengan sangat mudah, Langkah pertama guru mengupdate status sebagai contoh "bagaimanakah pendapat anda tentang hukum mendatangi dukun?", Siswa dengan mudah menyatakan pendapat dengan mengomentari pertanyaan guru, Variasi lainnya adalah guru membuat tautan dengan materi yang akan disampaikan, Siswa membaca dan dapat menyimpulkan apa yang guru sampaikan, dan Guru juga dapat melihat, dan mengawasi keseharian siswa sehingga dapat dilakukan bimbingan dengan baik

Pemanfaatan teknologi informasi ini apabila dimanfaatkan secara efektif akan cenderung tepat guna karena hampir sebagian besar siswa sekarang ini memanfaatkan media informasi dan jejaring sosial ini. Tanpa sebuah paksaan seorang anak akan dengan rela hati membaca dan mengikuti pembelajaran pendidikan agama Islam. Hal ini penulis pernah terapkan ketika memberikan pembelajaran akhlak di SMP Muh 10 Yogyakarta. sebagai ilustrasi : 

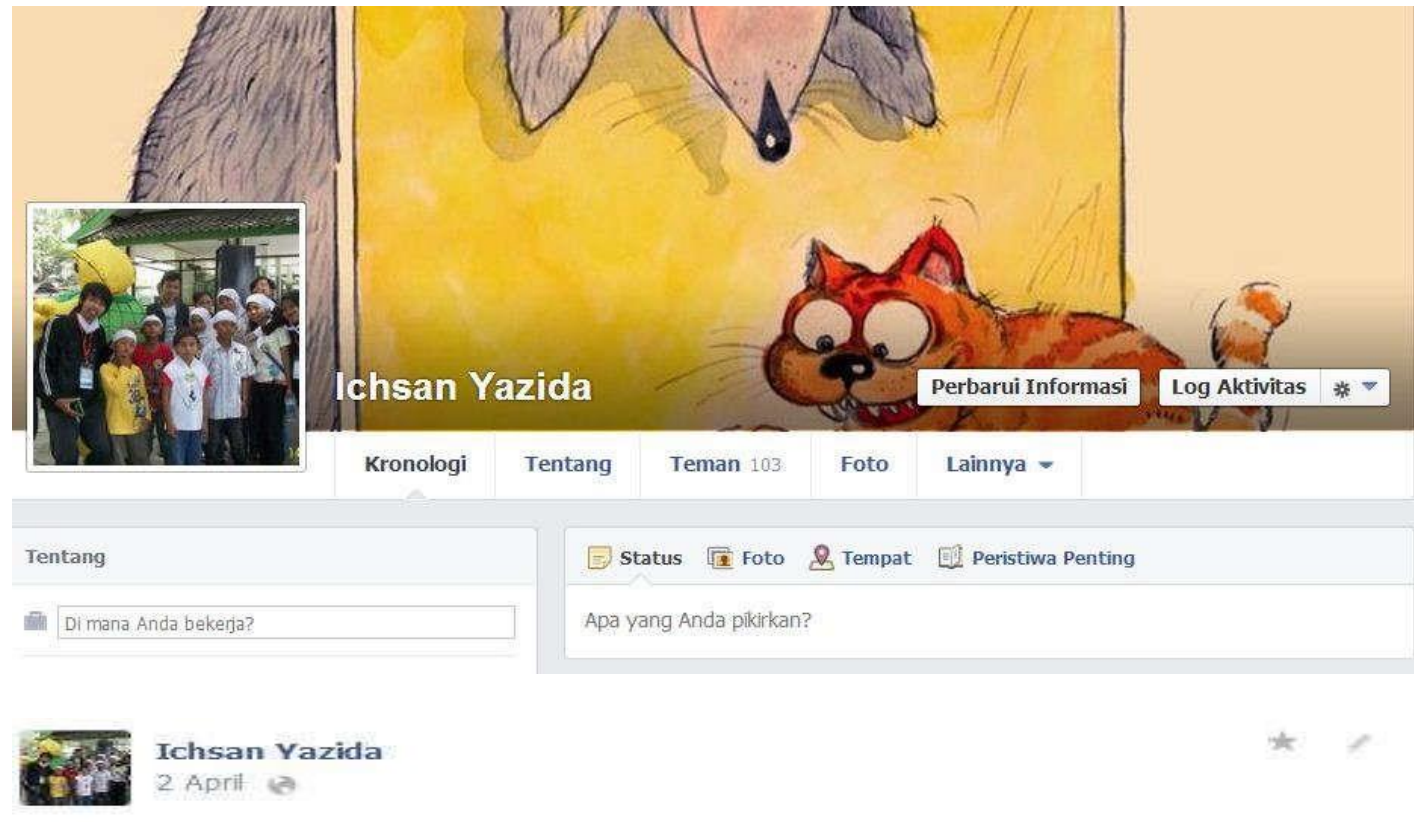

Ichsan Yazida

2 April 2

bagaimana pendapat anda berkaitan dengan dukun, horoskop dan pelet?? berikan alasan

\begin{abstract}
Suka - Komentari - Promosikan - Bagikan
Nur Adnan, AnisaNiisa, Axila Vilha dan 3 lainnya menyukai ini.
\end{abstract}

Lihat Komentar Sebelumnya

Angga Baswith Sanur Rkm JANGAN MENYEKUTUKAN ALLAH

2 April pukul $12: 04 \cdot$ Suka

Aditya Amoex'd Comunity jangan percaya kepada dukkun masuk kerumah dukun saja sholat 30 hari tidak diterima

2 April pukul 12:05 - Suka

Angga Baswith Sanur Rkm JANGAN MENYEKUTUKAN ALLAH

2. Apral pukul 12:05 - Suka

Dari ilustrasi diatas, facebook sebagai jejaring sosial dan informasi akan lebih fungsional dan memiliki nilai yang baik dengan memberikan hal-hal yang bermanfaat bagi siswa. Semua media pempunyai dua sumbu yang bertentangan : positif dan negatif. Apabila digunakan degan tepat, maka akan memnghasilkan efek positif, namun apabila digunakan dengan kepentingan yang tidak berguna maka akan menghasilkan efek negatif.Hal yang sangat perlu diperhatikan adalah, bahwa meskipun teknologi dapat digunakan akan tetapi sifatnya candu sehingga perlu adanya pendampingan.

Dengan mengamati pada pengalaman siswa dalam belajar, maka siswa yang terlibat dalam pembelajaran secara aktif maka daya ingat yang dimiliki cenderung lebih besar. Dengan kata lain, perkembangan siswa dengan mengalami secara langsung mencari dan melakukan eksplorasi berkaitan dengan teknologi, maka pengalaman yang dimiliki siswa semakin banyak pula. 


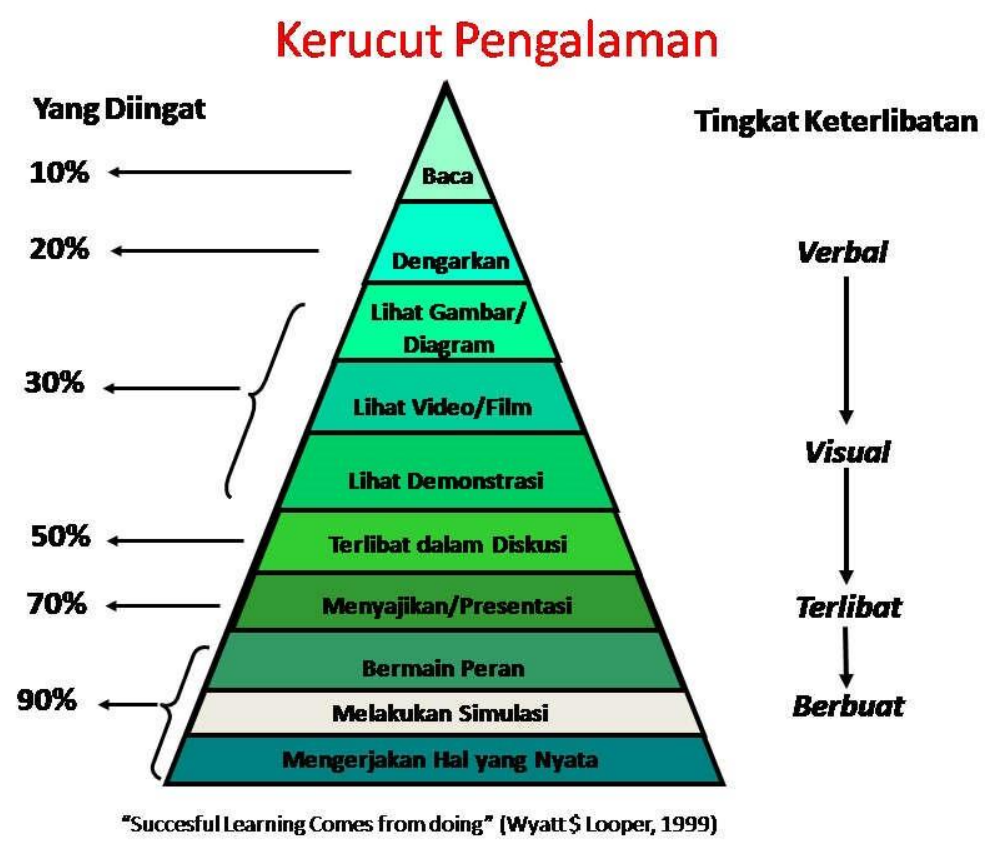

Disisi lain. Penggunaan facebook lebih mudah dibandingkan dengan e-learning (M.Kom, 2020). Mengapa demikian? Hal ini dikarenakan setiap siswa secara mudah dapat mengakses dan dengan mudah pula masuk dalam jejaring tersebut tanpa harus membuat program elearning. Adapun dalam penjabarannya, media dan kegiatan ini dapat include dalam kegiatan pembelajaran, diantarannya:

Penyusunan dan pelaksanaan instrumen Pembelajaran PAI (Silabus, RPP, Modul Bahan Ajar, Sistem Penilaian dan Analisis Instrumen Penilaian). Tersusunnya semua perangkat pembelajaran mulai Silabus sampai Analisis Instrumen Penilaian yang sudah dientri melalui computer.Tersedianya dan terlaksananya pembelajaran yang mengacu pada Bahan ajar pandang (visual) terdiri atas bahan cetak (printed) seperti antara lain handout, buku, modul, lembar kerja siswa, brosur, leaflet, wallchart, foto/gambar, dan non cetak (non printed), seperti model/maket.

Tersedianya dan terlaksananya pembelajaran yang mengacu pada Bahan ajar dengar (audio) seperti kaset, radio, piringan hitam, dan compact disk audio. Tersedianya dan terlaksananya pembelajaran yang mengacu pada Bahan ajar pandang dengar (audio visual) seperti video compact disk, film. Tersedianya dan terlaksananya pembelajaran yang mengacu pada Bahan ajar multimedia interaktif (interactive teaching material) seperti CAI (Computer Assisted Instruction), compact disk (CD) multimedia pembelajaran interaktif, dan bahan ajar berbasis web (web based learning materials).

Sistem Pembelajaran PAI sudah berbasis Teknologi Informasi dan Komunikasi (TIK) di mana setiap saat siswa bisa mengakses segala hal yang terkait dengan perencanaan, proses dan hasil pembelajarannya (Dewi Tri Santi, 2020). Kegiatan Mentoring/Tutorial Sebaya; Mentor sudah mengambil inisatif sendiri untuk menyampaiakan materi mentoring berbasis Bahan ajar multimedia interaktif (interactive teaching material) seperti CAI (Computer Assisted Instruction), compact disk. Sistem mentoring sudah berbasis Teknologi Informasi dan Komunikasi (TIK) di mana setiap saat siswa bisa mengakses segala hal yang terkait dengan perencanaan, proses dan hasil mentoringnya Kegiatan Mandiri Siswa. Ini bagian tugas siswa; Siswa dibimbing oleh GPAI untuk menyelesaikan tagihan, tugas kegamaan di sekolah sudah berbasis computer. Siswa dibimbing oleh GPAI untuk menyelesaikan tagihan, tugas kegamaan di rumah sudah berbasis computer. Siswa dibimbing oleh GPAI untuk 
menyelesaikan tagihan, tugas kegamaan di masyarakat sudah berbasis computer. Siswa dibimbing oleh GPAI untuk menyelesaikan tagihan, tugas kegamaan di sekolah, rumah dan masyarakat sudah berbasis computer.

Sistem Kegiatan Mandiri Siswa sudah berbasis Teknologi Informasi dan Komunikasi (TIK) di mana setiap saat siswa bisa mengakses segala hal yang terkait dengan perencanaan, proses dan hasil kegiatan mandirinya.Berdasarkan Renstra tersebut, membutuhkan banyak kolaborasi dan kerjasama dengan berbagai pihak. Tentu saja pula, dana dan sarana lain perlu mendapatkan perhatian, sehingga segalanya dapat berjalan sesuai dengan asa dan rencana. Apa yang penulis tuangkan ini, berdasarkan pengalaman sehari-ahari penulis dalam proses pembelajaran PAI. Namun, harus diakui pemanfaatan ICT dalam proses pembelajaran PAI tidak sepenuhnya dilakukan secara berkesinambungan, karena sarananya sendiri belum memungkinkan.

\section{Simpulan}

Facebook sebagai sebuah jejaring sosial pada dasarnya sangat efektif digunakan untuk media pebelajaran dan strategi pembelajaran PAI. Hal ini disamping sangat mudah diakses dan dapat dinikmati oleh seluruh siswa di sekolah di dalam penerapan pembelajaran. Disisi lainnya facebook yang cenderung digandrungi siswa agaknya lebih bermanfaat apabila digunakan untuk pembelajaran. Guru dapat mengawasi secara langsung tindak-tanduk yang dilakukan oleh siswa diluar sekolah dengan melihat pada status dan kata-kata yang diungkapkan seorang siswa. Guru dengan mudah juga dapat mengakses informasi secara baik untuk diberikan kepada seorang siswa.

Dari penerapan salah satu teknologi informasi khususnya facebook, maka seorang guru dapat dimudahkan dalam beberapa hal, yaitu; Para siswa cenderung antusias di dalam mengikuti pembelajaran, Seorang guru dapat lebih mudah mengakses dan memberikan penilaian secara online, Guru hanya memposisikan sebagai mentor dan para siswa dapat belajar secara mandiri sehingga mengalami secara langsung, Para siswa dengan mudah menemukan jawaban atas pertanyaan dan pernyataan yang disampaikan seorang guru, Pembelajaran tidak hanya dilakukan di kelas saja, tetapi dapat dilakukan dimanapun, tidak terikat jarak dan waktu, Penggunaan teknologi informasi yang tepat akan menciptakan pemanfaatan teknologi yang positif sehingga dapat fungsional.

Dari beberapa kemudahan diatas, pembelajaran PAI yang digunakan di sekolahsekolah pada umumnya akan lebih mudah dan mengikuti perkembangan zaman. informan yang tersedia tidak hanya satu, melainkan sangat banyak sumber yang memperkuat daya asah dan penasaran siswa untuk belajar lebih maju.

Anggapan negatif ini adalah tidak benar kerana aspek ilmu-ilmu berkaitan dengan kebendaan seperti aspek sains dan teknologi merupakan ilmu yang senantiasa berkembang dan saling memberikan sumbangan antara ilmu yang sebelumnya dengan yang sesudahnya. Hal ini berarti, sains dana teknologi Islam yang pernah mengalami kejayaan merupakan sumbangan terbesar dalam pengembangan sains dan teknologi barat.

Bagi pihak yang menafikan peranan umat Islam dalam sains atau peranannya sekadar memindahkan dari filsafat Yunani, berarti juga telah penafian hukum sains yang berbasis kepada pengembangan di samping penafian realitas kejayaan umat Islam dalam sejarah umat manusia.

Realitas sejarah membuktikan bahwa dari sisi kualitas, kemajuan sains daan teknologi umat Islam pernah melampaui kualitas sains dan teknologi pada saat ini, bisa dilihat dengan kualitas ilmuwan dan karya-karya yang dihasilkan. Adapun dari sisi kuantitas, kejayaan sains dan teknologi umat Islam sangat lama, sehingga kejayaan Barat dalam penguasaan sains dan teknologi belum sebanding dengan lamanya kejayaan sains dan teknologi Islam.

Kemajuan sains dan teknologi Barat modern merupakan hasil pemindahan dari kejayaan sains dan teknologi Islam di Baghdad, Spanyol dan Kepulauan Sicily. Realitas ini secara historis harusnya mampu membangkitkan motivasi kepada umat Islam untuk bangkit dari 
ketertinggalan dalam bidang sains dan teknologi.

Saat ini, Barat sedang mengalami kejayaan di bidang sains dan teknologi, akan tetapi krisis kepercayaan juga melanda merekaa karena sekulerisme dan atheisme yang mereka anut. Adapun Islam, saat ini sedang berupaya menguasai sains dan teknologi Barat, belum sampai pada persaingan dalam produksi sains dan teknologi. Kebangkitan sains dan teknologi dapat ditempuh jika ada upaya integrasi secaya nyata ilmu umum dengan agama.

\section{Daftar Pustaka}

Adipura, B. (2018). Pengaruh Model pembelajaran Sains-Teknologi-Masyarakat dalam Meningkatkan Literasi Sains dan Teknologi ditinjau dari Gaya Kognitif Siswa. AlTadzkiyyah: Jurnal Pendidikan Islam, 8, 75-83.

https://media.neliti.com/media/publications/177430-ID-peran-teknologi-informasidan-komunikasi.pdf

Anshori, S. (2019). Pemanfaatan Teknologi Informasi Dan Komunikasi Sebagai Media Pembelajaran. Civic-Culture: Jurnal Ilmu Pendidikan PKn Dan Sosial Budaya, 2(1), 88100.

Dewi Tri Santi. (2020). PEMANFAATAN MEDIA SOSIAL DALAM KEGIATAN BELAJAR MENGAJAR PADA MASA COVID-19 DI MI AL-IMAN WAY JEPARA. As-Salam: Jurnal Studi Hukum Islam \& Pendidikan, 9(2), 145-162. https://doi.org/10.51226/assalam.v9i2.145

Habibah, S. (2017). Dosen Filsafat pada Fakultas Agama Islam Universitas Islam Darul Ulum Lamongan 166. DAR EL-ILMI : Jurnal Studi Keagamaan, Pendidikan Dan Humaniora, 4(1), 166-180.

Hariyanto, D. (2019). PENDIDIKAN BERBASIS TEKNOLOGI , PERMASALAHAN DAN TANTANGANNYA.

Hokanson, B., Clinton, G., Tawfik, A. A., Grincewicz, A., \& Schmidt, M. (2020). Educational Technology Beyond Content: A New Focus for Learning. Springer International Publishing. https://books.google.co.id/books?id=zk3cDwAAQBAJ

Imro'Atus, S., Lara, L. L., \& Nina, M. (2017). Konsep Pendidikan Teknologi. Jurnal Edik Informatika, 4, 1-21. http://eprints.umsida.ac.id/1864/1/TP makalah kel.1 Bag.3 Revisi.pdf

M.Kom, A. (2020). Pemanfaatan Media Sosial Sebagai Media Pembelajaran Pada Mahasiswa Perguruan Tinggi Di Sumsel. Jurnal Digital Teknologi Informasi, 1(2), 64. https://doi.org/10.32502/digital.v1i2.2371

Maha, A. (2019). Hubungan Berpikir Kritis Dengan Perkembangan Teknologi Modern. https://doi.org/10.31227/osf.io/bz46c

Pangalo, E. G. (2020). Pembelajaran Mobile Learning. Jurnal Teknologi Pendidikan, 5(1), 3856. https://jurnal.ikipmataram.ac.id/index.php/jtp/article/view/2851/1980

Ramirez, J. M., \& Garcia-Segura, L. A. (2017). Cyberspace: Risks and Benefits for Society, Security and Development. Springer International Publishing. https://books.google.co.id/books?id=mzTbDgAAQBAJ

Retno, D. (2019). Sejarah Perjalanan Facebook, dari Kamar Asrama Menghubungkan Dunia. https://sejarahlengkap.com/teknologi/sejarah-berdirinya-facebook

Setiadi, A. (2016). Pemanfaatan media sosial untuk efektifitas komunikasi. Jurnal Ilmiah Matrik, 16(1).

Sudiksa, I. G. Y. (2016). Hilangnya Budaya Membajak Sawah Dengan Menggunakan Sapi Akibat Perkembangan Teknologi Traktor. Media Komunikasi FPIPS, 15(2), 46-50.

Susanti, R. (2013). Teknologi Pendidikan Dan Peranannya Dalam Transformasi Pendidikan. Jurnal Teknologi Pendidikan, 2(2), 15-23. https://doi.org/10.32832/tek.pend.v2i2.448 